\title{
PRAGMATIC POLITENESS OF THE IMPERATIVE SPEECH USED BY THE ELEMENTARY SCHOOL LANGUAGE TEACHERS
}

\author{
Afifah Raihany ${ }^{1}$, Eva Nikmatul Rabbianty ${ }^{2, *}$ \\ ${ }^{1}$ English Teaching Learning Program, Tarbiyah Faculty, Institut Agama Islam Negeri Madura, Pamekasan \\ 69371, Indonesia \\ ${ }^{2}$ English Teaching Learning Program, Tarbiyah Faculty, Institut Agama Islam Negeri Madura, Pamekasan \\ 69371, Indonesia
}

\section{ARTICLE INFO}

Keywords:

Imperative pragmatic

Imperative speech

Politeness

Pragmatics

Article History:

Received: 18/09/2020

Accepted: 28/05/2021

Available Online:

31/05/2021

\begin{abstract}
A B S T RACT
As a means of communication, the politeness aspect of language always comes together with interpersonal communication. People can reflect politeness in communication activities through their verbal language. This research aims to analyze and describe the elementary school language teachers' imperative speech focusing on the form, meaning, and imperative pragmatic politeness. This study is descriptive qualitative research. The data were teachers' speeches during the teaching-learning process. The data were collected by using the observation method with observing, recording, and note-taking techniques. The imperative pragmatic meaning of the prohibition and interrogative speech describes the pragmatic meaning of imperative commands widely used by SD Integral Lukman al-Hakim Sumenep language teachers. Meanwhile, according to Leech's politeness principles, the teachers use six maxims categories; tact maxim, generosity maxim, approbation maxim, modesty maxim, agreement maxim, and sympathy maxim. In addition, imperative speech with the complete agreement is also found, namely in the form of action as a student's reaction to the teacher's imperative speech; the findings also prove that imperative speech found in the imperative form and the non-imperative form of politeness. Both of the politeness in the speech of the Language teacher forms are based on the construction of Leech's politeness principles.
\end{abstract}

2442-305X / (C) 2021 The Authors, this is open access article under the (CC-BY-NC) license (https://creativecommons.org/licenses/by-nc/4.0/), DOI: 10.19105/ojbs.v15i1.3810

\footnotetext{
$\overline{\text { * Corresponding Author: }}$

Email address: eva@iainmadura.ac.id (E. N. Rabbianty)
}

\section{A. Introduction}

Humans as social creatures need to interact with each other. The interaction possibly occurs by using language. Language as a system has specific structures and rules that its speakers must obey. ${ }^{1}$ Therefore, language contains rules that govern how a person speaks so that the language users' interpersonal relationships are well maintained. As

1 Abdul Chaer, Kesantunan Berbahasa, (Jakarta: Rineka Cipta (Jakarta: Rineka Cipta, 2010), 14. 
stated by $\mathrm{Yu}$ in Song, the technical rules of the language, known as pragmalinguistics, employed to properly express what the speaker wants to communicate to the hearer. ${ }^{2}$ Without this organizational knowledge, communication in the language becomes extremely difficult. Language is a means of social communication and has special functions. One of the functions can be found in utterances that contain imperatives. In everyday life and formal education, we surely often find Imperative speeches. In the Indonesian context, the imperative words are usually used to order someone, for example 'get in' (silahkan masuk), 'please' (tolong), 'come on' (ayolah). In its usual form, the imperative speech ends with an exclamation point (!).

On the other hand, when we see them from a pragmatic perspective, nonimperative sentences can also function to command or order (imperative). In other words, it is imperative speech, which is constructed as non-imperative pragmatically, can mean imperative. One example is the teacher's imperative speech when teaching students, "Prepare your stationery and textbooks now!". (siapkan alas tulis dan buku kalian, sekarang!). A teacher used this utterance to his students when they were about to start a lesson. Meanwhile, "When you are ready, this morning the lesson will start as usual" (kalau kalian sudah siap, pagi ini pelajaran akan dimulai!)", The utterances

\footnotetext{
2 Sooho Song, Politeness and Culture in Second Language Acquisition (London: Palgrave Macmillan UK, 2012), https://doi.org/10.1057/9781137030634.
}

mean imperative pragmatics in the form of non-imperative speech. From the example above, it can be concluded that imperative speech does not only functions as an imperative but also a non-imperative sentence.

According to Keraf, imperative speech is a speech that contains orders or requests for other people to do something that the person in charge desires. Alisyahbana also conveyed the same thing that imperative speech is a speech that give commands ${ }^{3}$ (forces, orders, invites, asks) so that the person who is ordered to do what is stated in the order. ${ }^{4}$ Likewise, Kridalaksana says that imperative speech is a sentence or verb to express an order or obligation or prohibition of acting. Meanwhile, according to Rahardi, the imperative sentence contains ordering or asking the hearer to do something as the speaker wants. ${ }^{5}$

The linguists' opinion above concludes that imperative speech is a command addressed by the speaker to the hearer, both in writing and orally, that demands action from the hearer under the speaker's demands in the sentence's predicate. Based on its form, imperative speech is divided into two forms, namely (1) formal or structural imperative forms

3 Gorys Keraf, Tatabahasa Rujukan Bahasa Indonesia (Jakarta: PT. Grasindo, 1991), 206.

4 S. Takdir Alisyahbana, Tata Baru Bahasa Indonesia Jilid 1 (Jakarta: Dian Rakyat, 1978), 73.

5 R. Kunjana Rahardi, Pragmatik: Kesantunan Imperatif Bahasa Indonesia (Jakarta: PT Gelora Aksara Pratama, 2006), 79. 
and (2) pragmatic or nonstructural imperative forms. ${ }^{6}$

The imperative form includes two kinds of things: the imperative formal form and the imperative pragmatic form. Pragmatic form realizes the imperative meaning of the Indonesian language concerning the context of the speech situation. ${ }^{7}$ Unlike the imperative structural form, the imperative pragmatic form is not only an imperative construction but can also be a non-imperative construction.

Non-imperative construction is imperative speech whose meaning is expressed indirectly (implicitly), both in declarative and interrogative constructs. This explanation is in line with Rahardi's thought, non-imperative speech can be called an indirect imperative whose pragmatic meaning can only be known through the context of the speech situation that underlies and embodies it. $^{8}$ Thus, it is clear that many of the utterances around us contain particular imperative pragmatic meanings, but their construction form is non-imperative speech. Only the speech situation context can determine when a speech will be interpreted as a pragmatic imperative.

Rahardi explained at least seventeen kinds of imperative pragmatic meanings in Indonesian. ${ }^{9}$ The seventeen kinds of imperative pragmatic meanings are utterances that contain imperative pragmatic meanings of commands, orders, asking, requests, insistences,

\footnotetext{
${ }^{6}$ Rahardi, 87.

7 Rahardi, 93.

8 Rahardi, 94.

${ }^{9}$ Rahardi, 94.
}

persuasions, appeals, invitations, requests for permission, permits, prohibitions, hopes, cursings, congratulations, suggestions and "ngelulu" " (give someone what they want and more, sarcastically, even though one does not agree).

we cannot separate between Imperative speech as a form of interpersonal communication between teachers and students and the politeness aspect of language. ${ }^{10}$ As a statement that says, a language reflects a person's personality is absolute. ${ }^{11}$ It means that with language, we can judge a person's character. If the use of the language is excellent and full of politeness, our selfimage will be ok. A person with a lively personality will manifest in polite language. The teacher is one of the models and role models for students to be polite in language. That is the importance of language politeness, so teachers and students should use polite language to achieve a conducive learning process to produce maximum learning results. Research suggested that it mediates teachers' identification of students as

\footnotetext{
10 Lakof in Song defines politeness as 'a system of interpersonal relations designed to facilitate interaction by minimizing the potential for conflict and confrontation inherent in all human interchanges' (see Song, Politeness and Culture in Second Language Acquisition, 16.

${ }^{11}$ A Fasulo mentions that language contributes to structuring the categories of experience and forming ideas about the functioning of the human mind. Therefore it reflects a person's personality, see more A. Fasulo, "Learning Through Narrative Socialization," in International Encyclopedia of Education (Third Edition), ed. Penelope Peterson, Eva Baker, and Barry McGaw (Oxford: Elsevier, 2010), 303-9, https://doi.org/10.1016/B978-0-08044894-7.00498-X.
} 
ready, willing, and able to learn. ${ }^{12}$ Furthermore, the process of building the students' moral character can happen along the way.

Politeness in a language is reflected in communication procedures through verbal signs or language procedures. Every language user must understand that language not only conveys messages, ideas, and thoughts but also builds social harmony through language procedures that must follow the cultural elements that exist in the community. Pranowo argues that the markers in the use of certain words as a choice of words reflect someone's politeness, including the use of word choices, such as: please, sorry, thank you, sir/ma'am. ${ }^{13}$

Language is essential to create appropriate communication activities. Bruce Fraser discusses language politeness based on strategy. ${ }^{14}$ It means that politeness is part of speech. The interlocutor's/ speaker's politeness determines that he should not exceed his rights and fulfill his interlocutor's obligations. Leech expressed the same thing; language politeness will be fulfilled if everyone can obey the maxims of communication principles. $^{15}$ Leech

\footnotetext{
12 Adrienne Lo and Kathryn M. Howard, "Mobilizing Respect and Politeness in Classrooms," Linguistics and Education 20, no. 3 (2009): 211-16, https://doi.org/10.1016/j.linged.2009.07.001.

13 Rahardi, Pragmatik: Kesantunan Imperatif Bahasa Indonesia, 63.

14 Bruce Fraser, "Perspectives on Politeness," Journal of Pragmatics 14, no. 2 (1990): 219-36, https://doi.org/10.1016/0378-2166(90)90081-N.

15 Geoffrey Leech, Prinsip- Prinsip Pragmatik (Jakarta, 2011), 31.
}

classifies the principle of politeness into six maxims as follows ${ }^{16}$ :

First, maxims of wisdom (tact) or discernment reduce others' losses and increase others' benefits. ${ }^{17}$ The center of this maxim is the commissive illocution. In other words, speech participants adhere to multiplying the speech partners' benefits rather than the speakers themselves in speaking activities.

Second, the maxim of generosity, manifested by making the least possible self-benefit, makes the most significant possible to lose yourself. ${ }^{18}$ That is, respect for others is more significant than himself. The center of the maxim of generosity is the commissive illocution.

Third, the maxim of approbation, manifested by criticizing others as little as possible, praises others as much as possible. Speech occurs in the form of expressive and assertive illocution. ${ }^{19}$ In other words, speech that contains praise or appreciation to the other party will increase politeness.

Fourth, the expression of simplicity or modesty manifested in as little selfpraise, self-deprecating as much as possible. $^{20}$ Speech can occur in expressive and assertive illocution. We can say that the speaker is polite if the speaker is humble.

Fifth, the maxim of agreement is manifested by reducing the mismatch between oneself and others; Increase the

16 Song, Politeness, and Culture in Second Language Acquisition, 22.

17 Song, 22.

18 Song, 23.

19 Song, 23.

20 Song, 23. 
conformity between yourself and others. ${ }^{21}$ The explanation above concludes that this maxim emphasizes that speech participants can foster compatibility in speaking activities. If there is an agreement between the speaker and the speech partner in speaking activities, then each of them can be said to be polite. Speech can occur in assertive illocution.

Sixth, the maxim of sympathy, the speech participants can maximize the sympathy attitude between one party and another. $^{22}$ Reducing the antipathy between oneself and others and increasing sympathy between oneself and others are ways to optimize sympathy. This speech can occur in an assertive illocution. Rahardi states that imperative pragmatic politeness based on the speech context is divided into two, namely, in the construction of declarative and interrogative speech.

Austin differentiates declarative sentences based on their meaning into constative sentences and performative sentences. Constative sentences are sentences that contain mere statements, while performative sentences are sentences that contain activity. ${ }^{23}$ What the speaker says contains what he does. This performative sentence is included in imperative pragmatics. Meanwhile, interrogative speech is used to ask the partner to do something. According to Rahardi, interrogative speech to express

\footnotetext{
21 Song, 23.

22 Song, 23.

23 Abdul Chaer and Leonie Agustina., Sosiolinguistik Perkenalan Awal (Jakarta: Rineka Cipta, 2004), 51.
}

the imperative pragmatic meaning can imply an immense enough meaning of indirect speech. Imperative speech with interrogative construction can also state several meanings, such as those found in declarative speech, namely interrogative speech, which states the imperative pragmatic meaning of orders, invitations, requests, courtesies, and prohibitions.

From the explanation of several experts above, it can be concluded that communication activities will be practical if the speaker and the interlocutor obey several rules contained in the principle of communication so that the activity can avoid misunderstandings. One aspect that needs to be considered in using language is the aspect of politeness. A person's verbal language can reflect his/her politeness in communication activities through spoken or written words.

This research is not new. Several previous research studies that can be used as a basis for development as a comparison include; First, research by Nababan. ${ }^{24}$ The results of this study indicate that (1) there is an appearance of politeness in the form of verbal and nonverbal directive speech acts in the learning process at Taman Rama National Plus Jimbaran Junior High School, namely imperative, declarative and interrogative speech forms (2) there is a politeness function of directive speech acts in the learning process in namely politeness in

\footnotetext{
24 Mei Lamria Entalya Nababan, "Kesantunan Verbal dan Nonverbal pada Tuturan Direktif dalam Pembelajaran di SMP Rama National Plus Jimbaran," Jurnal Pendidikan dan Pembelajaran Bahasa Indonesia 1 (2012): 1-20.
} 
the speech act function invites, orders ask, begs, suggests and prohibits, (3) there are deviations in the principles of verbal and non-verbal politeness in the learning process in SMP, namely deviation from the principles of hospitality and friendship, not forcing and not seem arrogant, and indirect or fenced principles. From the results of this study, it can be drawn a common thread that there are three forms of directive speech acts and five functions of directive speech act, and three deviations from the principle of politeness in the learning process at SMP Taman Rama National Plus Jimbaran.

Second, the research conducted by Montolalu et al. ${ }^{25}$ As a result of this study, (1) there is politeness in the form of imperative verbal and nonverbal speech in the learning process, (2) there is a principle of imperative verbal and nonverbal politeness in the learning process, (3) there is a deviation from the principle of verbal and nonverbal politeness in an imperative speech in the process of teaching and learning at SMP Pangudi Luhur Ambarawa, Central Java.

Third, "Verbal and Nonverbal politeness of Abdi Dalem Keraton Ngayogyakarta Hadiningrat" By Yogatama $^{26}$ reveals that (1) the form of verbal language politeness is 60

25 D. E. Montolalu, I. N. Suandi, and I. M. Sutama, "Kesantunan Verbal dan Nonverbal pada Tuturan Imperatif dalam Pembelajaran Bahasa Indonesia di SMP Pangudi Luhur Ambarawa Jawa Tengah," EJournal Program Pascasarjana Universitas Pendidikan Ganesha 2 (2013): 1-10.

26 Timotius Tri Yogatama, "Kesantunan Berbahasa Verbal dan Nonverbal Abdi Dalem Keraton Ngayogyakarta Hadiningrat" (Thesis, Yogyakarta, Universitas Sanata Dharma, 2017). obedience to Leech's maxims with details of 11 utterances of wisdom maxims, 12 maxim of generosity, seven maxims of praise, 14 maxims humility, and eight maxims of agreement and sympathy. Meanwhile, according to Brown and Levinson, 54 speeches are obeying positive politeness and six hostile politeness speeches. In addition to the 60 speech data above is also equipped with forms of nonverbal language politeness in paralinguistic, kinesic, and artifactual with details of 24 paralinguistic elements, 23 kinesic elements, and 13 artifactual elements. The functions of those elements are smoothing, affirming, and complementing verbal speech. (2) the researcher found five markers Verbal and nonverbal language politeness, which consists of choosing a language as a marker of politeness, choosing diction, paralinguistic elements, kinesics, and artifacts. (3) there are five rules of language politeness, namely olah wicara ( the art of communication), olah wirama (the art of rhyming), olah wiraga (the art of movement), olah wirasa (the art of feeling), olah busana (the art of dressing).

Wahyu Lailul Fadli also carried out the results of further research on "Imperative Speeches in Communication between Mobile Sellers and Buyers at Matahari Singosaren"27 concluded that: (1) there were five imperative utterances used in communication between

\footnotetext{
27 Wahyu Lailul Fadli, "Kesantunan Tuturan Imperative dalam Komunikasi antara Penjual Handphone dengan Pembeli di Matahari Singosaren" (Thesis, Surakarta, Universitas Muhammadiyah Surakarta, 2012).
} 
cellphone sellers and buyers at Matahari Singosaren Plaza Solo; namely the sentence's regular imperatives, requests, granting permits, invitations, and orders. (2) there are five kinds of imperative speech politeness in the communication between cellphone sellers and buyers at Matahari Singosaren Plaza Solo. Including the declarative, imperative, interrogative, exclamative, and emphatic constructions.

The study's limitation, which only discusses the pragmatic politeness of imperative speech based on the context of the speech and the principles of Leech's politeness makes this research different from previous studies.

Based on the phenomena above, theoretical studies, and research results, the researcher is interested in examining the pragmatic politeness of the imperative speech of SDIT Language Teachers Lukman al-Hakim, sumenep district deeply.

\section{B. Method}

This research is a qualitative descriptive study that aims to describe SD Integral Lukman al-Hakim language teachers' imperative speech, which focuses on the form, meaning, and imperative pragmatic politeness of building the students' good character values.

This study's data source came from the utterances produced by the teacher of Indonesian and English at the fourth grade to the sixth grade of SD Integral Lukman al-Hakim, Sumenep City District. The method of collecting data in this study using the observation method with observing, recording, and note-taking techniques. Several techniques are used to obtain representative data from the listening method, such as listening without participating and detailed note-taking while listening based on the research objectives. The researchers observed eight thematic Indonesian class teachers and 4 English teachers from grade 4 to grade 6 during the teaching and learning process. And from the observation during the teaching and learning process conducted by the teacher of SD Integral Lukman al-Hakim Sumenep, one of the districts in Madura, east Java Indonesia, the researcher then found 75 utterances containing imperative meanings. Then the data were analyzed by using the politeness theory by Leech.

\section{Results}

Based on the observations and interviews conducted on May 13 - July 19, 2019, from 8 thematic Indonesian class teachers and 4 English teachers from grade 4 to grade 6 during the teaching and learning process, this study found 75 utterances containing imperative meanings. The following is the complete data exposure: 
Table 1.

the Language Teachers' Imperative Speeches

\begin{tabular}{|c|c|c|}
\hline No. & Utterances (in Bahasa Indonesia) & Translation \\
\hline 1. & "Berdoa sebelum belajar ya!" & "Please, pray before you are studying!" \\
\hline 2. & "Ya sudah, silahkan dikerjakan!" & "Yes, please do it!" \\
\hline 3. & “Jangan bergurau!” & "Do not joke around!" \\
\hline 4. & “Kerjakan dulu!” & "Do it first!" \\
\hline 5. & “Ayo ayo, semuanya kita mulai dari awal!" & "Come on, let us all start from the beginning!" \\
\hline 6. & "Eh nanti tidak ada pertanyaan ya?" & "There are no questions later, Ok?" \\
\hline 7. & "Nanti kalian taruh depan atau belakang ya?" & "Will you put it in front or in the back?" \\
\hline 8. & "Sssttt, nggak ada pertanyaan lagi!" & "Shhh, no more questions!" \\
\hline 9. & "Riko, gunakan Bahasa Indonesia ya ko!" & "Riko, use Indonesian please!" \\
\hline 10. & "Tidak usah ramai!" & "Don’t make any noise!" \\
\hline 11. & "Yang masuk, diabsen sama ustazah." & "I will call your name." \\
\hline 12. & $\begin{array}{l}\text { "Mohon catat secepatnya di papan! Entar saya } \\
\text { hapus nak." }\end{array}$ & $\begin{array}{l}\text { "Please write down what is on the board as } \\
\text { soon as possible! I'll delete it, kid." }\end{array}$ \\
\hline 13. & "Hey Reza, kamu itu main terus." & "Hey Reza, you keep on playing." \\
\hline 14. & "Zidan, lihat!" & "Zidan, look!" \\
\hline 15. & $\begin{array}{l}\text { "Tolong, kalau mau pinjam tipe X pamit dulu ke } \\
\text { Ustazah ya!” }\end{array}$ & $\begin{array}{l}\text { "Please, tell Ustazah if you want to borrow my } \\
\text { type X!" }\end{array}$ \\
\hline 16. & $\begin{array}{l}\text { "Ega... Ega, kaos kakinya kok ngak di pakek } \\
\text { Ega? di pakek ya?" }\end{array}$ & $\begin{array}{l}\text { "Ega ... Ega, why aren't you wearing the } \\
\text { socks? use it, huh?" }\end{array}$ \\
\hline 17. & "Lexa bicara terus tapi belum selesai" & $\begin{array}{l}\text { "Lexa keeps on talking but do not finish your } \\
\text { work." }\end{array}$ \\
\hline 18. & "Hey Eko, besok remedi Bahasa Arab ya?" & $\begin{array}{l}\text { "Hey Eko, you have an Arabic remedy } \\
\text { tomorrow, is that right?" }\end{array}$ \\
\hline 19. & "Gak usah ramai bukan pasar." & $\begin{array}{l}\text { "No need to be crowded. It is not in the } \\
\text { market." }\end{array}$ \\
\hline 20. & "Beni, letakkan tasnya temannya, Beni!" & "Beni, put down your friend’s bag!" \\
\hline 21. & $\begin{array}{l}\text { "Coba koreksi lagi, jangan sampai ada yang gak } \\
\text { di isi!" }\end{array}$ & $\begin{array}{l}\text { "Try correcting it again, do not let anything not } \\
\text { filled!" }\end{array}$ \\
\hline 22. & “Kerjakan, jangan ngerjakan yang lain!” & "Do it, do not do anything else!" \\
\hline 23. & "Faiq,coba biarkan saja Alexa!" & "Faiq, just try to leave Alexa!" \\
\hline 24. & "Coba dengarkan Ustazah dulu nak! Sssstt" & "Try to listen to the Ustazah first, kid! Shush" \\
\hline 25. & $\begin{array}{l}\text { "Ayo, cepat habiskan makanan itu Hen! Sekarang } \\
\text { waktunya belajar tematik." }\end{array}$ & $\begin{array}{l}\text { "Come on, quickly finish the food, Hen! Now is } \\
\text { the time to study thematic. " }\end{array}$ \\
\hline 26. & $\begin{array}{l}\text { "Bu guru mau ngasih pengumuman. Telinganya } \\
\text { dipasang buat mendengarkan." }\end{array}$ & $\begin{array}{l}\text { "The teacher wants to give an announcement. } \\
\text { Listen carefully." }\end{array}$ \\
\hline 27. & "Mas Raffi, duduk yang rapi!" & "Mas Raffi, sit down tightly!" \\
\hline
\end{tabular}


28. "Selamat bagi yang tidak remedi! Tapi jangan lupa, mohon besok tetap masuk!"

29. "Mohon, jangan berbicara terus ya nak!"

30. "Ayo, selesaikan!"

31. "Bak Kalis, hadap ke depan!"

32. "Siapa yang ramai?"

33. "Ayo, kerjakan sendiri!"

34. "Silahkan duduk!"

35. "Ayo, dijawab sendiri!"

36. "Ayo, coba diteliti lagi!"

37. “Ayo, yang sudah selesai salat, duduk!"

38. "Silahkan dikerjakan dengan tertib!"

39. "Kasih nama jangan sampai lupa ya!"

40. "Jarum jam di angka 3 baru boleh Tanya."

41. "Gak pakai nyontek!"

42. "Tidak usah bertanya artinya!"

43. "Silahkan dikoreksi lagi!"

44. "5 menit silahkan dikumpulkan!"

45. "Yang dipanggil maju ya?"

46. "Mana punyamu?"

47. "Sini, bawa kesini!"

48. "Jam 10 pas kalau belum selesai ustazah ambil."

49. "Yang sudah, kartunya taruh depan."

50. "Dengarkan dulu ya!"

51. "Dengarkan! Besok remedi Matematika sama tematik!"

52. "Mohon dipelajari semuanya"

53. "Nizar duduk dulu!"

54. "Yang tematik belajar tema 6."

55. "Ustazah Minta tolong ngoreksi ya!"

56. "Ssstt jangan ramai!"

57. "Sudah silahkan dikumpulkan!"

58. "Lihat, ada titiknya itunya kan?"
"Congratulations to those who do not remedy! Nevertheless, do not forget, please come in tomorrow! "

"Please, do not keep talking, students!"

"Come on, finish it!"

"Bak Kalis, face forward!"

"Who make the noise?"

"Come on, do it yourself!"

"Please sit down!"

"Come on, answer yourself!"

"Come on, try to research again!"

"Come on, those who have finished praying, sit down!"

"Please do it in an orderly manner!"

"Put your name on, do not forget it!"

"If the hour hand on number 3 , then you can ask questions."

"No cheating!"

"Do not ask the meaning!"

"Please correct it again!"

"Please collect in 5 minutes!"

"The one who is called come forward, ok?"

"Where is yours?"

"Here, bring it here!"

"At 10 o'clock, if you have not finished, ustazah will take it."

"Those who has finished put the card in front."

"Listen to it first!"

"Listen! Tomorrow is the Math and thematic remedy!"

"Please learn everything."

"Nizar, sit down first!"

"Learn the thematic book, theme 6."

"Ustazah, please correcting it for me!"

"Shhh, do not be crowded!"

"Please collect it!"

"Look, there is a point on it, right?" 
59. "Ya, gak terlalu besar."

60. "Ayo, jangan biasakan tanya artinya!"

61. "Ayo, jawabannya tidak untuk ditanyakan!"

62. "Mejanya tidak untuk dibelok belok ya!"

63. "Silahkan duduk nak! Nanti ustazah kebangkunya."

64. "Kalau duduk diusahakan tidak menggokmenggok biar badan dan tulangnya tidak bengkok dan bagus."

65. "Nin, ayo kerjakan sendiri!"

66. “Azka, silahkan duduknya Azka!"

67. "Mbak tidak berembuk?bagus!"

68. "Apa yang dirembuk tadi?"

69. Percakapan:

a. Walas :"Bisakah dimulai?

b. Murid: "Belajar 5 menit ustazah"

c. Walas: "Baiklah, buka bukunya dulu!"

70. "Yuk,waktunya sudah habis!"

71. "Nadin...Nadia, tidak mengganggu yang lain ya?"

72. Percakapan:
a. Walas: "Kenapa?"
b. Murid: "Tidak tahu ustazah"
c. Walas: "Coba selesaikan dulu!"

73. "Nilai yang terbanyak yang mana?"

74. "Ada yang punya pencil?"

75. “Apakah dikelas ini sering ramai?"
"Yes, it is not too big."

"Come on, do not easily ask for the translation!"

"Come on, and the answer is not to share!"

"Do not turn around the table!"

"Sit down, kid! ustazah will go to your seat later. "

"When sitting, try to sit straight for a good posture."

"Nin, let us do it yourself!"

"Azka, please sit down!"

"You do not share the answers? Good!"

"What was the discussion earlier?"

Conversation:

a. Teacher: "Can we start?"

b. Students: "Only for 5 minutes, OK ustazah?"

c. Teacher: "All right, open your book!"

"Come on, the time is up!"

"Nadin ... Nadia, do not bother the others, huh?"

Conversation:

a. Teacher: "why?"

b. Students: 'I do not know, Uztadzah"!

c. Teacher: "Please, finish it first!"

"Which one is the highest score?"

"Anyone has a pencil here!"

"Is this class always as crowded as this?"
From the data above, the researcher then sorted them out based on the focus of the research formulated, namely the form, meaning, and imperative pragmatic politeness based on the context of speech and the principles of Leech politeness.
1. The Imperative Pragmatic Forms in the Speech of the Language Teachers.

The imperative pragmatic form found in the speech of SD Integral Lukman al-Hakim language teachers, Sumenep includes imperative forms and non-imperative forms. These speeches can be seen in the following table: 
Table 2.

The imperative Pragmatics speech used by the language teachers of SD Integral Lukman al-Hakim Sumenep City.

\begin{tabular}{llll}
\hline Total & Speech data number & Form & Category \\
\hline 49 & $1,2,3,4,5,8,9,10,12,14,15$, & Imperative & Imperative Pragmatic \\
& $20,21,22,23,24,25,27,28,29$, & & Speech \\
& $30,31,33,34,35,36,37,38,39$, & & \\
& $41,42,43,44,47,50,51,52,53$, & & \\
& $55,56,57,60,61,63,65,66,69$, & & \\
& $70,72$. & & \\
& & & \\
12 & Declarative & & \\
& $11,13,17,19,26,40,48,49,54$, & \\
& $59,62,64$ & \\
& Interrogative & \\
& $6,7,16,18,32,45,46,58,67,68$, & \\
& $71,73,74,75$ & \\
\end{tabular}

*please refers to table 1 for the speech/sentences.

Based on data exposure at table 1, the imperative pragmatic form found in the speech of SD Integral Lukman al-Hakim language teacher includes imperative forms and non-imperative forms. In detail, there are 75 imperative speeches, 49 are imperative, and 26 are non-imperative speech. In addition, there are two nonimperative forms of speech, namely the declarative form and interrogative. In detail, there are 12 speeches in declarative form, and in the interrogative form are 14 speeches. To simplify the presentation, here is the data in the table form.

\section{The Imperative Pragmatic Speech of SD Integral Language Teachers of Lukman al-Hakim Sumenep City}

Based on the pragmatic form in Table 1, it is found that 12 kinds of imperative pragmatic forms, namely 1) command, 2) order, 3) request, 4) pressure, 5) appeal, 6) indulgence, 7) invitation, 8) giving permission (allow), 9) prohibition, 10) congratulations and appeals 11) urges and prohibitions, and 12) urges and orders. There are three meanings from the twelve forms (giving congratulations, urges and prohibitions, urges and orders) which are simultaneously spoken in one context of speech. The three forms are found in this research. The following is a table of the results of imperative pragmatic politeness contained in the speech of Language teachers 
Table 3.

The imperative Pragmatics speech used by the language teachers of SD Integral Lukman al-Hakim Sumenep City.

\begin{tabular}{|c|c|c|c|c|c|}
\hline \multirow[t]{3}{*}{ No } & \multirow[t]{3}{*}{ Meaning } & \multicolumn{3}{|c|}{ The number of data based on speech form } & \multirow[t]{3}{*}{ Total } \\
\hline & & \multirow[t]{2}{*}{ Imperative } & \multicolumn{2}{|l|}{ Non-imperative } & \\
\hline & & & Declarative & Interrogative & \\
\hline 1. & Command & $\begin{array}{l}1,4,9,14,20,22,27 \\
31,47,50,51,53\end{array}$ & $11,26,49,54$ & $\begin{array}{l}7,16,18,32 \\
46,58,73\end{array}$ & 23 \\
\hline 2. & Order & $21,23,24,72$ & - & - & 4 \\
\hline 3. & Request & $15,39,55$ & - & 74 & 4 \\
\hline 4. & Pressure & $25,30,33,37,65,70$ & 48 & - & 7 \\
\hline 5. & Appeal & $12,29,52$ & - & - & 3 \\
\hline 6. & Madness & $\begin{array}{l}2,34,38,43,44,57 \\
63,66\end{array}$ & - & - & 8 \\
\hline 7. & Invitation & 5,35 & - & 45 & 3 \\
\hline 8. & Allowance & 69 & 40,59 & - & 3 \\
\hline 9. & Prohibition & $3,8,10,41,42,56,60$ & $13,17,19,62,64$ & $6,67,68,71,75$ & 17 \\
\hline 10. & Congratulation + Advice & 28 & - & - & 1 \\
\hline 11. & Pressure + Prohibition & 61 & - & - & 1 \\
\hline 12. & Pressure + Command & 36 & - & - & 1 \\
\hline \multirow{2}{*}{\multicolumn{2}{|c|}{ Total }} & 49 & 12 & 14 & 75 \\
\hline & & & 26 & & \\
\hline
\end{tabular}

75

In this study, 49 utterances contain imperative pragmatics, which was imperatively manifested in imperative construction with directly expressed meaning. Besides, imperative speech can be manifested in a non-imperative form. This non-imperative speech implies a pragmatic imperative with a high degree of indirect speech. The High levels of indirect speech also have high levels of politeness. The use of declarative or interrogative constructs of speech usually has the characteristic of being indirect. It can be said that a speech that has an indirect nature can be said that it contains the intentions of politeness. The higher the indirect level of the speech, the higher the level of politeness in the speech. In line with Rahardi's statement, nonimperative speech to express imperative pragmatic intent contains a high degree of indirect speech. Because of the high degree of indirect speech, these utterances have a high degree of politeness. ${ }^{28}$

28 Rahardi, Pragmatik: Kesantunan Imperatif Bahasa Indonesia, 145. 
The meaning of imperative pragmatics can be seen through declarative or interrogative speech. These utterances can carry the meaning of indirect speech. Based on its meaning, in declarative speech, performative sentences are included in imperative pragmatics. As Austin defines, "a performative sentence is a sentence that contains act." 29 What the speaker says contains what he does. Likewise, with interrogative speech, this speech is used to ask something of the speech partner. $\mathrm{He}$ also said that interrogative speech to express the imperative pragmatic meaning could imply a large enough meaning of indirectness ${ }^{30}$ Imperative speech with interrogative construction can also express several meanings, such as those found in declarative speech.

\section{Imperative Pragmatic Politeness} Based on Leech Politeness Principles and Speech Construction in SD Integral Language Teachers Lukman al-Hakim Sumenep City

Based on table below, the researcher found six types of maxims based on the 26 data found; there are 17 data showing maxims agreement. The fewest ones found were the maxims of approbation and sympathy, namely only 2 data, 26 non-imperative utterances were found that fulfilled the imperative pragmatic politeness based on speech construction. The most interrogative speech construction was found, namely

29 Chaer and Leonie Agustina, Sosiolinguistik Perkenalan Awal, 51.

${ }^{30}$ Chaer and Leonie Agustina, 142.
14 speech data consisting of 4 imperative pragmatic meanings, namely 7 data on the meaning of orders, 1 data on the meaning of requests, 1 data on the meaning of invitation, and 5 data meaning of prohibitions. Meanwhile, 12 declarative constructed speech data have four imperative pragmatic meanings, namely 4 data on the meaning of orders, 1 data on the meaning of pressure, 2 data on granting permission, and 5 data on prohibition. The findings data can be seen in the following table.

Table 4.

Pragmatic Imperative Politeness Based on Leech Politeness Principles and Speech Construction.

\begin{tabular}{llll}
\hline No. & Maxim Type & Data & Total \\
\hline 1. & Tact & $\begin{array}{l}26,32, \\
54,58,73,\end{array}$ & 5 \\
& & 11,67 & 2 \\
2. & Approbation & 13,64 & 2 \\
3. & Sympathy & $6,16,18$, & 11 \\
4. & Agreement & $19,40,45$, & \\
& & $48,59,68$, & \\
& & 71,74 & \\
5. & Tact + Agreement & $7,46,75$ & 3 \\
6. & Sympathy + & $17,49,62$ & 3 \\
& Agreement & & \\
\hline Total & & 26 \\
\hline
\end{tabular}

\section{Discussion}

\section{Imperative Pragmatic Politeness Based on the Speech Construction}

The use of non-imperative utterances to express the pragmatic imperative usually contains an element of indirect speech. ${ }^{31}$ The element of indirect

31 Rahardi, Pragmatik: Kesantunan Imperatif Bahasa Indonesia, 134. 
speech has higher politeness than direct imperative speech. Indirectness is indeed receiving the highest rating of politeness, ${ }^{32}$ it is more preferred by some bilinguals. $^{33}$ Indirectness is preferred because they enable speakers to avoid politeness effect, and in such circumstances, optimally relevant stimuli for requesting. ${ }^{34}$ In other words, nonimperative utterances contain aspects of imperative pragmatic politeness. In this study, it was found that non-imperative speech with declarative and interrogative constructs.

The research data under the category of imperative pragmatic politeness found that there were 26 nonimperative speech data in declarative and interrogative constructs.

\section{a. Imperative Pragmatic Politeness in Declarative Speech}

The twenty-six utterances consist of 4 imperative pragmatic meanings. There are 5 data imperative pragmatic meanings (utterances number 13, 17, 19, 62, and 64). The second sequence is occupied by the imperative pragmatic meaning 4 data (speech numbers 11, 26, 49 and 54).

32 Shoshana Blum-Kulka, "Indirectness and Politeness in Requests: Same or Different?," Journal of Pragmatics 11, no. 2 (1987): 131-46, https://doi.org/10.1016/0378-2166(87)90192-5.

33 Leyla Marti, "Indirectness and Politeness in Turkish-German Bilingual and Turkish Monolingual Requests," Journal of Pragmatics, Focus-on Issue: Intercultural Pragmatics and Sociolinguistics, 38, no. $11 \quad$ (2006): $1836-69$, https://doi.org/10.1016/j.pragma.2005.05.009.

34 Nicolas Ruytenbeek, "Indirect Requests, Relevance, and Politeness," Journal of Pragmatics $142 \quad$ (2019): 78-89, https://doi.org/10.1016/j.pragma.2019.01.007.
Furthermore, declarative speech means permitting (utterances number 40 and 59) and insistence is 2 data and 1 data only (utterances number 48). From these data, the language teachers of SD Integral Lukman al-Hakim Sumenep uses more declarative speech, which implies prohibition in the teaching and learning process.

Declarative speech is one of the choices for language teachers at SD Integral Lukman al-Hakim, Sumenep. In particular, it states the imperative pragmatic meaning of prohibition because the non-imperative speech in declarative construction is more polite when compared to imperative speech, which is expressed directly. Here are some examples of discussion:

(17) "Lexa keeps on talking but does not finishing your work."

Speech context: a Speech delivered by the teacher when he saw one of his students talking to himself without caring about the assignment that should be done in class.

(64) "When you are sitting, try to sit straight for a good posture."

Speech context: The teacher conveys this speech to his students when they sit on their sides and not straight up during the learning process.

These utterances are declarative utterances that contain the imperative pragmatic meaning of prohibition. This imperative can be called an indirect imperative whose pragmatic meaning can only be known through the underlying 
speech situation. In the speech (17), the teacher tells Lexa his students not to talk continuously indirectly. Whereas in speech (64), the teacher prohibits his students from sitting on their side and not straight up by giving reasons that are easy for the students to understand. In the example of the speech above, it can be concluded that the pragmatic meaning of the imperative of prohibition is not always expressed by direct imperative construction. The non-continuity of the speech mentioned is a form of politeness that the speaker has to the interlocutor to convey its meaning.

\section{b. Pragmatic Imperative Politeness in Interrogative Speech}

Imperative speech can take the form of non-imperative speech. ${ }^{35}$ Nonimperative speech is not only declarative but also interrogative, it can be used as requests and commands. ${ }^{36}$ Similar to declarative speech, this interrogative speech also has a higher politeness value than direct imperative speech. In this study, interrogative utterances have pragmatic imperative meanings of orders, prohibitions on invitations and requests. Each of these imperative pragmatic

\footnotetext{
${ }^{35}$ Birjulin and Xrakovski in Jary and Kissine define imperative sentences as semantically conveying the idea that the speaker informs the hearer that he wishes some action (by a certain agent) to be caused by this very information. See more Mark Jary and Mikhail Kissine, "When Terminology Matters: The Imperative as a Comparative Concept," Linguistics 54, no. 1 (2016): 119-48, https://doi.org/10.1515/ling-2015-0039.

${ }^{36}$ Alexander K. Oglobin, "Imperative Sentences in Javanese," in Typology of Imperative Construction, ed. Victor S. Xrakovski (Munich: Lincom, 2001), 221-42.
}

meanings consists of 7 data (speech number $7,16,18,32,46,58,73), 5$ data (utterances number 6, 67, 68, 71, 75) and 1 data each for the imperative pragmatic meaning of invitation and request (utterances 45 and 74).

This interrogative speech is also used by SD Integral Lukman al-Hakim language teachers, Sumenep City District, especially when the language teachers order something to their students. The following example of speech can be considered to clarify the above statement.

(32) "Who is busy?

Speech context: a teacher's speech when some students are noisy and crowded.

(58) "Look, there is a full stop, right?"

Speech context: when the teacher gave a speech during the exam, one of the students looked confused with his exam questions.

Like declarative speech, these speech utterances are interrogative utterances containing the pragmatic imperative meaning of orders. This imperative can be called an indirect imperative whose pragmatic meaning can only be known through the context of the speech situation that also lies behind it. In utterance (32), this non-imperative form implies an order. The teacher ordered his students to be quiet. This interrogative constructed speech is an attempt to convey the teacher's intention implicitly so that the students are silent. Likewise, in speech (64), the meaning of the command 
that the teacher spoke interrogatively was the teacher instructing the student to examine the punctuation marks on the exam question in the form of a question. The declarative and interrogative speech above is imperative speech which has higher politeness than direct imperative speech.

\section{c. Imperative Pragmatic Politeness Based on Leech Politeness Principles}

Table 4. above presents the imperative pragmatic politeness based on Leech politeness principles and speech construction in SD Integral Elementary School teachers' speech Lukman alHakim, Sumenep City district.

Based on the table above, six maxims are found, 2 of which are a combination of 2 maxims. 1) Maxim of tact: by maximizing others' benefits, the person has implemented the maxim of wisdom. The imperative pragmatic speech politeness of SD Integral Lukman alHakim language teachers is found in five speech data. 2) Maxim of Approbation can be made by adding praise to others or reducing criticism, or insults against others. In other words, people are considered polite if they always give appreciation to other parties.

In this study, two speech data were found. 3) Maxim of Sympathy, it is hoped that speech participants can maximize sympathy between one party and another. This research found two speech data, 4) Maxim of agreement, which can be made by increasing self-conformity with others. The speech partner can see the maxim from the speech partners' reactions after hearing the speakers' speech. These reactions can be in the form of words or actions.

The study found 11 speech data. The agreement is shown more through actions according to the teacher's commands. This means that students as speech partners can show maximal agreement on any non-imperative speech that contains the teacher's imperative pragmatic meanings. 5) Maxim of tact and agreement found three speech data containing a combination of 2 maxims. 6) The maxims of sympathy and agreement were also found in 3 speech data containing a combination of 2 maxims.

This study's results will theoretically contribute to the development of linguistics, especially regarding imperative speech (such as Koo and Rhee; ${ }^{37}$ Ryabova; $^{38}$ and Terkourafi $^{39}$ ). Besides that, it can be used as reference material to enrich the repertoire of science in general and society as a whole and evidence that the use of imperative speech in communication, especially in the teaching and learning process. The result also showed that politeness use is in the form of imperative and also non-

\footnotetext{
37 Hyun Jung Koo and Seongha Rhee, "'I Will Do It... but I'm Asking You to Do It': On the Emergence of Polite Imperative from Promissive," Procedia Social and Behavioral Sciences 97 (2013): 487-94, https://doi.org/10.1016/j.sbspro.2013.10.263.

38 Marina Ryabova, "Politeness Strategy in Everyday Communication," Procedia - Social and Behavioral Sciences 206 (2015): 90-95, https://doi.org/10.1016/j.sbspro.2015.10.033.

39 Marina Terkourafi, "The Puzzle of Indirect Speech," Journal of Pragmatics 43, no. 11 (September 1, 2011): 2861-65, https://doi.org/10.1016/j.pragma.2011.05.003.
} 
imperative. Practically, it is hoped that it can provide knowledge and understanding of imperative politeness to be applied in the teaching process, primarily when the teacher uses imperative speech. Besides, imperative forms and imperative modesty can be applied in everyday life. Other than that, the results of this study will later contribute primary data to be used as a basis for further research.

\section{Conclusion}

Thus, two forms, namely imperative and non-imperative speech, are found in the language teacher's communication. Viewed from Leech's politeness principles, it is identified that the most imperative speech used by the language teacher is in the form of agreement maxims. Furthermore, based on the construction of the speech, interrogative and declarative speech were also used. Interrogative speech, which states the imperative command's pragmatic meaning, is the most commonly found in this study. Besides that, declarative speech of the imperative pragmatic politeness, which states the meaning of prohibition imperative pragmatic, is most widely used by language teachers.

Imperative speech as a form of interpersonal communication between teachers and students cannot be separated from the politeness aspect of language. As a saying says, language reflects a person's personality as real. It means that with language, we can judge a person's character. If the use of the language is excellent and full of politeness, our self-image will be good. A person with positive character will manifest polite language. The teacher is one of the models and role models for students to be polite in language. Because of the importance of language politeness, so, teachers and students should use polite language so that a conducive learning process can be achieved to produce maximum learning results.

\section{References}

Alisyahbana, S. Takdir. Tata Baru Bahasa Indonesia Jilid 1. Jakarta: Dian Rakyat, 1978.

Blum-Kulka, Shoshana. "Indirectness and Politeness in Requests: Same or Different?" Journal of Pragmatics 11, no. 2 (1987): 131-46. https://doi.org/10.1016/03782166(87)90192-5.

Chaer, Abdul. Kesantunan Berbahasa, (Jakarta: Rineka Cipta. Jakarta: Rineka Cipta, 2010.

Chaer, Abdul and Leonie Agustina. Sosiolinguistik Perkenalan Awal. Jakarta: Rineka Cipta, 2004.

Fadli, Wahyu Lailul. "Kesantunan Tuturan Imperative dalam Komunikasi antara Penjual Handphone dengan Pembeli di Matahari Singosaren." Thesis, Universitas Muhammadiyah Surakarta, 2012.

Fasulo, A. "Learning Through Narrative Socialization." In International Encyclopedia of Education (Third Edition), edited by Penelope Peterson, Eva Baker, and Barry McGaw, 303-9. Oxford: Elsevier, 2010. https://doi.org/10.1016/B9780-08-044894-7.00498-X.

Fraser, Bruce. "Perspectives on Politeness." Journal of Pragmatics 14, no. 2 (1990): 219-36. https://doi.org/10.1016/03782166(90)90081-N. 
Jary, Mark, and Mikhail Kissine. "When Terminology Matters: the Imperative as a Comparative Concept." Linguistics 54, no. 1 (2016): 119-48. https://doi.org/10.1515/ling-20150039.

Keraf, Gorys. Tatabahasa Rujukan Bahasa Indonesia. Jakarta: PT. Grasindo, 1991.

Koo, Hyun Jung, and Seongha Rhee. "I Will Do It... but I'm Asking You to Do It': On the Emergence of Polite Imperative from Promissive." Procedia - Social and Behavioral Sciences 97 (2013): 487-94. https://doi.org/10.1016/j.sbspro.201 3.10.263.

Leech, Geoffrey. Prinsip- Prinsip Pragmatik. Jakarta, 1993.

Lo, Adrienne, and Kathryn M. Howard. "Mobilizing Respect and Politeness in Classrooms." Linguistics and Education, Mobilizing Respect and Politeness in Classrooms, 20, no. 3 (2009):

211-16. https://doi.org/10.1016/j.linged.2009. 07.001 .

Marti, Leyla. "Indirectness and Politeness in Turkish-German Bilingual and Turkish Monolingual Requests." Journal of Pragmatics, Focus-on Issue: Intercultural Pragmatics and Sociolinguistics, 38, no. 11 (2006): 1836-69.

https://doi.org/10.1016/j.pragma.200 5.05.009.

Montolalu, D. E., I. N. Suandi, and I. M. Sutama. "Kesantunan Verbal dan Nonverbal pada Tuturan Imperatif dalam Pembelajaran Bahasa Indonesia di SMP Pangudi Luhur Ambarawa Jawa Tengah." E-Journal Program Pascasarjana Universitas Pendidikan Ganesha 2 (2013): 1-10. https://ejournal-

pasca.undiksha.ac.id/index.php/jurn al_bahasa/article/view/720.

Nababan, Mei Lamria Entalya. "Kesantunan Verbal dan Nonverbal pada Tuturan Direktif dalam
Pembelajaran di SMP Rama National Plus Jimbaran." Jurnal Pendidikan dan Pembelajaran Bahasa Indonesia 1 (2012): 1-20. https://ejournal-

pasca.undiksha.ac.id/index.php/jurn al_bahasa/article/view/309.

Oglobin, Alexander K. "Imperative Sentences in Javanese." In Typology of Imperative Construction, edited by Victor S. Xrakovski, 221-42. Munich: Lincom, 2001.

Rahardi, R. Kunjana. Pragmatik: Kesantunan Imperatif Bahasa Indonesia. Jakarta: PT Gelora Aksara Pratama, 2006.

Ruytenbeek, Nicolas. "Indirect Requests, Relevance, and Politeness." Journal of Pragmatics 142 (2019): 78-89. https://doi.org/10.1016/j.pragma.201 9.01.007.

Ryabova, Marina. "Politeness Strategy in Everyday Communication." Procedia - Social and Behavioral Sciences 206 (2015): 90-95. https://doi.org/10.1016/j.sbspro.201 5.10.033.

Song, Sooho. Politeness and Culture in Second Language Acquisition. London: Palgrave Macmillan UK, 2012.

https://doi.org/10.1057/9781137030 634.

Terkourafi, Marina. "The Puzzle of Indirect Speech." Journal of Pragmatics 43, no. 11 (2011): 2861-65. https://doi.org/10.1016/j.pragma.201 1.05.003.

Yogatama, Timotius Tri. "Kesantunan Berbahasa Verbal dan Nonverbal Abdi Dalem Keraton Ngayogyakarta Hadiningrat." Thesis, Universitas Sanata Dharma, 2017. 